and the theory of complex spectra of Heisenberg and Hund formed preliminary steps for the analysis of NeIr. A great part of the Nerr lines have now been classified by me in a term scheme exhibiting a perfect analogy to that of FI. The following table gives an example of this analogy:

\section{Absorption Bands of Liquid and Vapour Amines.}

BY measuring, below wave-length $4 \mu$, the absorption of secondary and tertiary solid and liquid amines, it was shown that the N-H bond has a strong characteristic absorption band around $3 \mu$ (Proc. U.S.

\begin{tabular}{|c|c|c|c|c|c|c|c|c|c|c|c|}
\hline \multicolumn{4}{|c|}{ F I. } & \multicolumn{4}{|c|}{ Ne II. } & & & & \\
\hline \multirow{2}{*}{ Term. } & \multirow{2}{*}{$j}$. & \multirow{2}{*}{ Term Value. } & \multirow{2}{*}{$\begin{array}{c}\text { Term } \\
\text { Difference. }\end{array}$} & \multirow{2}{*}{ Term. } & \multirow{2}{*}{$j}$. & \multirow{2}{*}{ Term Value. } & \multirow{2}{*}{$\begin{array}{c}\text { Term } \\
\text { Difference. }\end{array}$} & \multirow{2}{*}{$\begin{array}{l}\text { Hund's } \\
\text { 'Theory. }\end{array}$} & \multicolumn{3}{|c|}{ Interval Ratio. } \\
\hline & & & & & & & & & Landé. & Fi. & Ne II. \\
\hline$a^{2} P$ & $\begin{array}{l}2 \\
1\end{array}$ & $\begin{array}{c}135320 \\
134913 \\
(16 \cdot 6 \text { volt })\end{array}$ & 407 & $a^{2} P$ & $\begin{array}{l}2 \\
1\end{array}$ & $\begin{array}{c}270000 \\
269220 \\
(33 \cdot 4 \text { volt })\end{array}$ & {$[780]$} & ${ }^{3} P+2$ & & & \\
\hline${ }^{4} P$ & $\begin{array}{l}3 \\
2 \\
1\end{array}$ & $\begin{array}{l}58617 \cdot 0 \\
58342 \cdot 3 \\
58182 \cdot 3\end{array}$ & $\begin{array}{l}274 \cdot 7 \\
160 \cdot 0\end{array}$ & ${ }^{4} P$ & $\begin{array}{l}3 \\
2 \\
1\end{array}$ & $\begin{array}{l}117000 \cdot 0 \\
116482 \cdot 0 \\
116183 \cdot 0\end{array}$ & $\begin{array}{l}518 \cdot 0 \\
299 \cdot 0\end{array}$ & ${ }^{3} P+3_{1}$ & $1 \cdot 67$ & 1.72 & $1 \cdot 73$ \\
\hline${ }^{4} P^{\prime}$ & $\begin{array}{l}3 \\
2 \\
1\end{array}$ & $\begin{array}{l}45104 \cdot 8 \\
44981 \cdot 9 \\
44879 \cdot 2\end{array}$ & $\begin{array}{l}122 \cdot 9 \\
102 \cdot 7\end{array}$ & ${ }^{4} P^{\prime}$ & $\begin{array}{l}3 \\
2 \\
1\end{array}$ & $\begin{array}{l}89938 \cdot 2 \\
89715 \cdot 6 \\
89533 \cdot 1\end{array}$ & $\begin{array}{l}222 \cdot 6 \\
182 \cdot 5\end{array}$ & ${ }^{3} P+3_{2}$ & $1 \cdot 67$ & $1 \cdot 19$ & $1 \cdot 21$ \\
\hline${ }^{4} D$ & $\begin{array}{l}4 \\
3 \\
2 \\
1\end{array}$ & $\begin{array}{l}44035 \cdot 4 \\
43858 \cdot 8 \\
43714 \cdot 3 \\
43630 \cdot 9\end{array}$ & $\begin{array}{r}176 \cdot 7 \\
144 \cdot 5 \\
83 \cdot 4\end{array}$ & ${ }^{4} D$ & $\begin{array}{l}4 \\
3 \\
2 \\
1\end{array}$ & $\begin{array}{l}87022 \cdot 7 \\
86684 \cdot 9 \\
86435 \cdot 2 \\
86291 \cdot 1\end{array}$ & $\begin{array}{l}337 \cdot 8 \\
249 \cdot 7 \\
144 \cdot 1\end{array}$ & ${ }^{3} P+3_{2}$ & $\begin{array}{l}2 \cdot 33 \\
I \cdot 67\end{array}$ & $\begin{array}{l}2 \cdot 11 \\
1 \cdot 73\end{array}$ & $\begin{array}{l}2 \cdot 34 \\
1 \cdot 73\end{array}$ \\
\hline${ }^{4} S$ & 2 & $42595 \cdot 0$ & & ${ }^{4} S$ & 2 & $83178 \cdot 0$ & & ${ }^{3} P+3_{2}$ & & & \\
\hline
\end{tabular}

The complete term table for NeIr and the lists of classified lines with further details will be published elsewhere.

Laboratory " Physica,"

Amsterdam, May 24.

The Nomenclature of Ghromosome Groups.

IT is well known that several plants and animals have been found which have $(a)$ three, four, or more haploid groups of chromosomes, instead of the usual two. These groups are typically identical, not only in the number, but also in the nature of their members; thus being homologous groups. On the other hand (b), in certain genera, species, or subspecies, have been found the haploid number of chromosomes of which is two, three, or four, etc., times that of the half number of a basic species in the same genus. In typical cases of this kind these extra chromosomes are not homologous, or not completely homologous, with those of the basic group.

Now in the first case $(a)$, the words diploid, triploid, and tetraploid have been some time in use. It would be scarcely possible, in the writer's opinion, to change the application of the word 'diploid,' for example, and confine its use to case $b$, as has been lately suggested (O. F. I. Langlet, Svensk Bot. Tidskr., vol. 21, pp. $1-17$; 1927). The cytologists who are doing such praiseworthy work in counting the chromosomes in different genera are not compelled to make use of a Greek terminology already employed in a different sense. They may have recourse to the mother tongue, and the terms, single, double, triple, quadruple... multiple, convey no necessary implication of homology, and would hence suit case $b$. Or, if technical terms are wanted, they are at hand in the Latin, where uniplex, duplex, triplex, quadruplex . . multiplex, await application to case $b$.

Carnegie Institution of Washington, John Belling. Department of Genetics,

Cold Spring Harbor, Long Island, N.Y., May 27.
Nat. Acad. Sci., 12, 74; 1926). It seemed, from the data on various substances by other workers, that this was an overtone of a fundamental at $6 \mu$.

Measurements, with a rock-salt prism spectrometer, of the absorption of longer waves by liquid and vapour amines, have recently been made here. They show a weak $6 \mu$ band both for secondary and tertiary amines, so that this band cannot be taken as the fundamental of the $3 \mu \mathrm{N}-\mathrm{H}$, the latter being, then, a fundamental.

This is in harmony with the recent results of Ellis for aniline liquids, whose very accurate measurements below $2 \cdot 8 \mu$ showed a series of overtones characteristic of $\mathrm{N}-\mathrm{H}$, the calculated fundamental of the series extrapolating to $2 \cdot 8 \mu$, not to $6 \mu(\mathrm{J}$. Am. Chem. Soc., $49,347 ; 1927)$. E. O. Salant.

Physics Department, Johns Hopkins University, Baltimore, Maryland, U.S.A., May 19.

\section{Unauthorised Publication of the "Grammar of Science."}

Messrs. Stechert and Co., of New York, have issued, entirely without my sanction, a reprint of the last edition of my "Grammar of Science." Copies of the book have been recently sold in England. I should like to inform possible purchasers, through the columns of NATURE, that the book is unauthorised and can only be sold illegally in Great Britain.

Messrs. Stechert \& Co. kindly inform me, having regard to the issue of a new and revised edition, that "it is better "- - they do not say for whom - " to have the book constantly on the market." It is needless to add that the "Grammar of Science" in its last edition, without a thorough revision, is not a book such as I should wish to issue under my name ; it is not abreast of the recent advances in physical science and epistemology.

This is not the place to comment on the morality of American copyright law. Karl Pearson.

University College,

London, W.C.I.

No. 3008, VoL. 119] 